\title{
Optic neuritis in multiple sclerosis
}

\author{
Looking from a patient's eyes
}

\section{Figure A photograph taken in London by a patient with multiple sclerosis}

A. Before ON
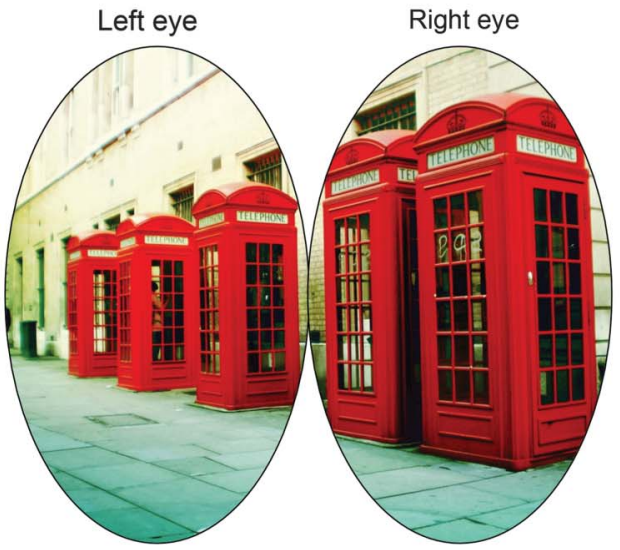

C. 4 weeks after onset of $\mathrm{ON}$
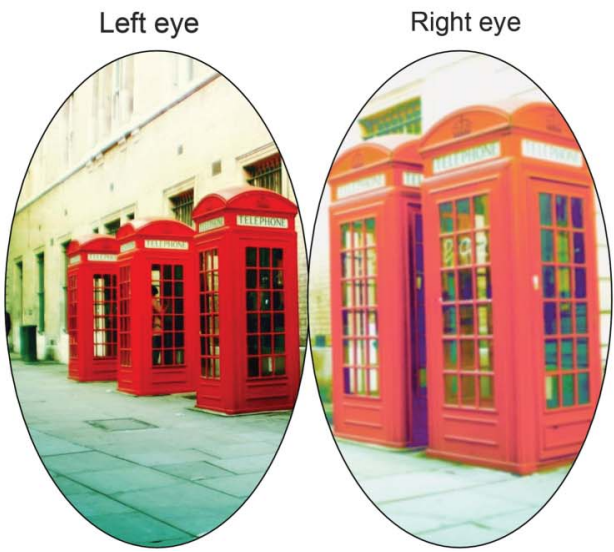

B. 2 weeks after onset of $O N$
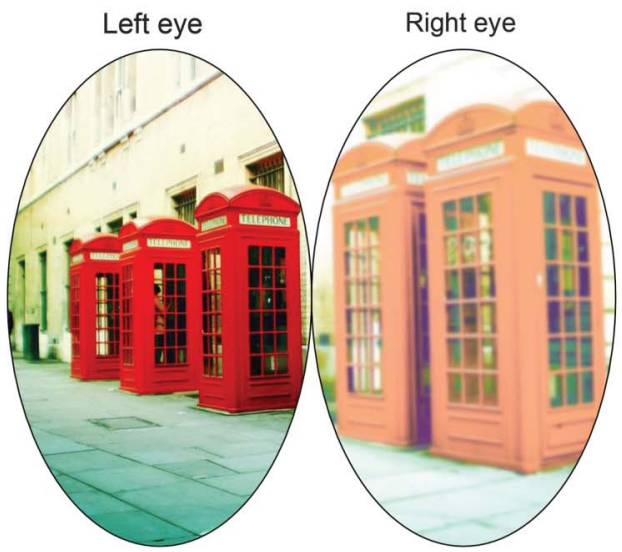

D. 6 months after onset of ON

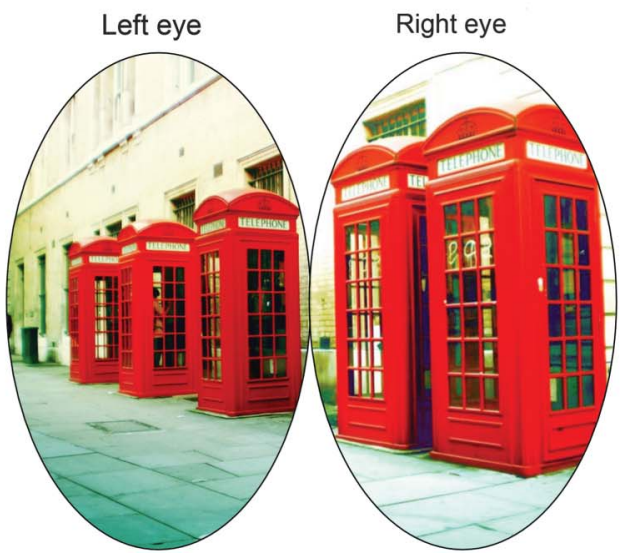

The original photograph (A) was modified by the patient himself together with the authors to represent the evolution of the patient's visual disturbances at week 2 (B), week 4 (C), and month 6 (D) after optic neuritis. See text for further details. Photograph reproduced with permission of the patient.

A 40-year-old writer, living in London, UK, had multiple sclerosis with right optic neuritis $(\mathrm{ON})^{1}$ confirmed by ophthalmologic and neurophysiologic evaluations. During $\mathrm{ON}$, he represented what he was able to see with his right eye. Two weeks later, blurred vision, decreased visual acuity, dyschromatopsia, and lower contrasts were still evident (figure, B). IV steroids therapy was administered. At week 4, color and contrast perception gradually improved (figure, C). Six months after ON, he experienced a partial vision recovery, with the persistence of an increased contrast perception (figure, D). These pictures provide insight regarding ONrelated visual changes, from a patient's perspective.

Paolo Preziosa, MD, Giancarlo Comi, MD, Massimo Filippi, MD

From the Neuroimaging Research Unit (P.P., M.F.) and Department of Neurology (P.P., G.C., M.F.), Institute of Experimental Neurology, Division of Neuroscience, San Raffaele Scientific Institute, Vita-Salute San Raffaele University, Milan, Italy.

Author contributions: Paolo Preziosa: interpretation of data, manuscript drafting, and manuscript revision. Giancarlo Comi: manuscript revision. Massimo Filippi: interpretation of data, manuscript drafting, and manuscript revision. 
Acknowledgment: The authors thank the patient for his availability.

Study funding: No targeted funding reported.

Disclosure: P. Preziosa received speakers honoraria from Biogen Idec, Novartis, and EXCEMED. G. Comi has received compensation for consulting services and/or speaking activities from Novartis, Teva Pharmaceutical Industries, Sanofi-Aventis Pharmaceuticals, Genzyme, Merck Serono, Biogen Dompé, Bayer Schering, Actelion, Serono Symposia International Foundation, Almirall, Chugai, and Receptos. M. Filippi serves on scientific advisory boards for Teva Pharmaceutical Industries; has received compensation for consulting services and/or speaking activities from Biogen Idec, EXCEMED, Novartis, and Teva Pharmaceutical Industries; and receives research support from Biogen Idec, Teva Pharmaceutical Industries, Novartis, Italian Ministry of Health, Fondazione Italiana Sclerosi Multipla, Cure PSP, Alzheimer's Drug Discovery Foundation (ADDF), the Jacques and Gloria Gossweiler Foundation (Switzerland), and AriSLA (Fondazione Italiana di Ricerca per la SLA). Go to Neurology.org for full disclosures.

Correspondence to Prof. Filippi: filippi.massimo@hsr.it

1. Toosy AT, Mason DF, Miller DH. Optic neuritis. Lancet Neurol 2014;13:83-99.

\section{Look What's New at the 2016 AAN Fall Conference}

Visit AAN.com/view/fall to register for the 2016 AAN Fall Conference, set for October 14-16, at The Cosmopolitan of Las Vegas. This is your year-end destination for acquiring the latest clinical advances in key disease states, improving your practice's efficiency and bottom line, and earning up to $15.75 \mathrm{CME}$ credits.

\section{Look What's New!}

- All-inclusive registration rate offers greater value than ever

- Flexible meeting format lets you build your own tailored schedule and select the programs of most interest-while on the go on-site

- New Topics: Update in Stroke, AAN Leadership University Course: Challenges of Leadership in Private Practice, Headache Skills Workshop (pre-registration required)

\section{Discover Altmetrics}

See real-time downloads and online activity for articles!

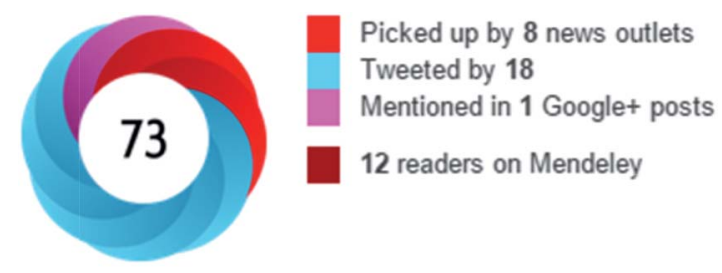

See more details

Authors and readers alike can view real-time data on articles including downloads and online activity across multiple sources. Click on the "Article Metrics" link in the right column of an article for details. To learn more about article metrics visit http://www.neurology.org/site/misc/article_usage.xhtml. 


\section{Neurology}

\section{Optic neuritis in multiple sclerosis: Looking from a patient's eyes \\ Paolo Preziosa, Giancarlo Comi and Massimo Filippi \\ Neurology 2016;87;338-339 \\ DOI 10.1212/WNL.0000000000002869}

\section{This information is current as of July 18, 2016}

\section{Updated Information \& Services}

\section{References}

Subspecialty Collections

\section{Permissions \& Licensing}

Reprints including high resolution figures, can be found at: http://n.neurology.org/content/87/3/338.full

This article cites 1 articles, 0 of which you can access for free at: http://n.neurology.org/content/87/3/338.full\#ref-list-1

This article, along with others on similar topics, appears in the following collection(s):

Clinical neurology examination

http://n.neurology.org/cgi/collection/clinical_neurology_examination Multiple sclerosis

http://n.neurology.org/cgi/collection/multiple_sclerosis

Optic nerve

http://n.neurology.org/cgi/collection/optic_nerve

Visual loss

http://n.neurology.org/cgi/collection/visual_loss

Information about reproducing this article in parts (figures,tables) or in its entirety can be found online at:

http://www.neurology.org/about/about_the_journal\#permissions

Information about ordering reprints can be found online:

http://n.neurology.org/subscribers/advertise

Neurology ${ }^{\circledR}$ is the official journal of the American Academy of Neurology. Published continuously since 1951, it is now a weekly with 48 issues per year. Copyright (O 2016 American Academy of Neurology. All rights reserved. Print ISSN: 0028-3878. Online ISSN: 1526-632X.

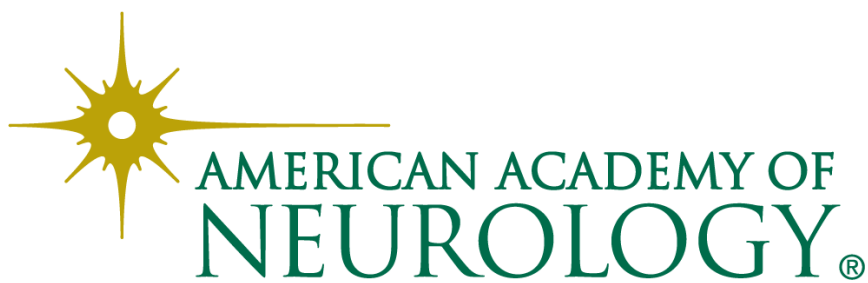

